\title{
Healthcare Workers as a Potential Source of Nosocomial Infections in the Regional Hospital of Korca, Albania
}

\author{
Zhinzela Qyli ${ }^{1}$, Laura Mezini ${ }^{2}$ \\ ${ }^{1}$ Nursing Department, University „'Fan S Nolieee, Korca, Albania \\ ${ }^{2}$ Nursing Department, University „„“Fqerem Cabejecee, Gjirokastra, Albania
}

\begin{abstract}
Objectives: The study was undertaken to make evident the role of healthcare workers as an important source in transmission of nosocomial infections in the Regional Hospital of Korca, Albania. Methodology: 169 swabs were taken from the hands, nose and throat of the healthcare workers in the hospital, doing the relevant bacteriological cultures. The swabs were cultured on Blood, MacConkey and Sabouro agars and incubated for $24 \mathrm{hrs}$ at $35 \pm 2{ }^{\circ} \mathrm{C}$. Results: 69 (40.8\%) cultures resulted positive and 100 (59.2\%) negative. From the positive bacterial isolates 59 ( 85.6\%) resulted with Staphylococcus aureus, 4 ( $5.8 \%$ ) isolates with E.coli, 1 ( $1.4 \%)$ with Proteus spp, 1 ( 1.4\%) with Klebsiella spp and 4 ( 5.8\%) with Staphylococcus epidermidis. Conclusions: The high percentage of pathogenic isolates through hospital workers at the Regional Hospital of Korca indicates a high potential risk of nosocomial infections in the hospital.
\end{abstract}

Keywords: pathogen, infections, healthcare workers

\section{Introduction}

Nosocomial infections comes from Greek words "nosus ${ }^{\text {ce }}$ meaning disease and ,komenion ${ }^{\text {ee }}$ meaning to take care of. Nosocomial infections can be defined as those occurring within 48 hours of hospital admission, 3 days of discharge or 30 days of an operation.

Modes of transmission. There are five modes of transmission: contact, vector borne, air borne, droplet and common vehicle.

1.Contact transmission. Most important and frequent mode of transmission of nosocomial infections is divided into two subgroups: direct contact transmission and indirect contact transmission. Direct contact transmission involves a direct body surface-to-body surface contact and physical transfer of microorganisms between a susceptible host and an infected or colonized person. Indirect contact transmission involves contact of a susceptible host with a contaminated intermediate object.

2.Vector transmission. Transmitted through insects and other invertebrates animals such as mosquitoes and fleas. 3.Droplet transmission. Droplet generated by sneezing, coughing or respiratory tract procedures like Broncoscopy or suction. 4.Air borne transmission. Tiny droplet nuclei that remain suspended in air. 5.Common vehicle transmission. Transmitted indirectly by materials contaminated with the infections.

Sources of infectious agents. Infectious agents transmitted during healthcare derive primarily from human sources but inanimate environmental sources also are implicated in transmission. Human reservoirs include patients, healthcare workers, and household members and other visitors. The endogenous flora of patients (e.g., bacteria residing in the respiratory or gastrointestinal tract) also are the source of nosocomial infections.

Healthcare workers can spread infection, in addition to contaminated equipment, bed linens, or air droplets. The role of health care workers in nosocomial infection transmission has been documented and the importance of hand washing in preventing such transmission has been understood. Healthcare professionals ${ }^{e e}$ hands represent the principal route of transmission of nosocomial pathogens. They are colonized permanently by the physiological flora ("resident flora") and temporarily, depending on the precise nature of the employee's duties, by various pathogens that do not belong to the physiological flora ("transient flora").

Droplet transmission is, technically, a form of contact transmission. Respiratory droplets carrying infectious pathogens transmit infection when they travel directly from the respiratory tract of the infectious individual to susceptible mucosal surfaces of the recipient, generally over short distances, necessitating facial protection. Respiratory droplets are generated when an infected person coughs, sneezes, or talks or during procedures such as suctioning, endotracheal intubation, cough induction by chest physiotherapy and cardiopulmonary resuscitation.

\section{Objective}

Healthcare workers can spread infections, so study was undertaken to make evident their role as an important source in transmission of nosocomial infections in the Regional Hospital of Korca, Albania.

\section{Methodology}

A number of 169 swabs were taken from the hands, nose and throat of the healthcare workes in different wards of the Regional Hospital of Korca, Albania, doing the relevant 


\section{International Journal of Science and Research (IJSR) \\ ISSN (Online): 2319-7064 \\ Index Copernicus Value (2013): 6.14 | Impact Factor (2014): 5.611}

bacteriological cultures. From these, 67 swabs were taken from the hands of the health care workers, 51 swabs from the nose and 51 from the throat. The swabs were cultured on Blood, Mac Conkey and Sabouro agars and incubated for $24 \mathrm{hrs}$ at $35 \pm 2{ }^{\circ} \mathrm{C}$. The isolates were identified with morphology and biochemistry.

\section{Results}

A total number of 69 cultures ( $40.8 \%$ ) have resulted positive and $100(59.2 \%)$ negative. $33.3 \%$ of the positive isolates corresponded to the cultures of the hands, $16 \%$ from the pharynges and $50.7 \%$ from the nose of the healthcare workers. From the positive bacterial isolates 59 ( 85.6\%) resulted with Staphylococcus aureus, 4 ( 5.8\%) isolates with E.coli, $1(1.4 \%)$ of the isolates with Proteus spp, $1(1.4 \%)$ with Klebsiella spp and 4 ( 5.8\%) with Staphylococcus epidermidis. From the swabs taken in the hands, 23 resulted positive. From these $15(65.2 \%)$ isolates were with Staphylococcus aureus, 4 (17.4\%) with E.Coli and 4 (17.4\%) Staphylococcus epidermidis. From the swabs taken in the throat, 11 resulted positive. From these 10 (91\%) isolates with Staphylococcus aureus and 1(9\%) was Klebsiella spp. The swabs taken in the nose resulted positive in 35 cultures: 34 ( 97.1\%) with Staphylococcus aureus and 1(2.9\%) with Proteus spp.

Table 1: The positivity of the isolates from the hands, throat and nose

\begin{tabular}{|c|c|c|c|}
\hline & Examined & Positive isolates & Percentage \% \\
\hline Hands & 67 & 23 & $33.3 \%$ \\
\hline Throat & 51 & 11 & $16 \%$ \\
\hline Nose & 51 & 35 & $50.7 \%$ \\
\hline Total & 169 & 69 & $100 \%$ \\
\hline
\end{tabular}

Table 2: The positivity of the isolates for the respective pathogen

\begin{tabular}{|c|c|c|}
\hline The pathogens & Nr of isolates & Percentage \\
\hline Staphylococcus aureus & 59 & $85.6 \%$ \\
\hline E.Coli & 4 & $5.8 \%$ \\
\hline Proteus spp & 1 & $1.4 \%$ \\
\hline Klebsiella spp & 1 & $1.4 \%$ \\
\hline Staphylococcus epidermidis & 4 & $5.8 \%$ \\
\hline Total & 69 & $100 \%$ \\
\hline
\end{tabular}

Table 3: The number of the positive isolates from the hands, throat and nose

\begin{tabular}{|l|c|c|c|c|c|}
\hline & $\begin{array}{c}\text { Nr of } \\
\text { positive } \\
\text { isolates } \\
\text { with } \\
\text { St.aureus }\end{array}$ & $\begin{array}{c}\text { Nr of } \\
\text { positive } \\
\text { isolates } \\
\text { with } \\
\text { E.coli }\end{array}$ & $\begin{array}{c}\text { Nr of } \\
\text { positive } \\
\text { isolates } \\
\text { with } \\
\text { Proteus } \\
\text { spp }\end{array}$ & $\begin{array}{c}\text { Nr of } \\
\text { positive } \\
\text { isolates } \\
\text { with } \\
\text { Kebsiella } \\
\text { spp }\end{array}$ & $\begin{array}{c}\text { Nr of positive } \\
\text { isolates with } \\
\text { St.epidermidis }\end{array}$ \\
\hline Hands & 15 & 4 & - & - & 4 \\
\hline Throat & 10 & - & - & 1 & - \\
\hline Nose & 34 & - & 1 & - & - \\
\hline Total & 59 & 4 & 1 & 1 & 4 \\
\hline
\end{tabular}

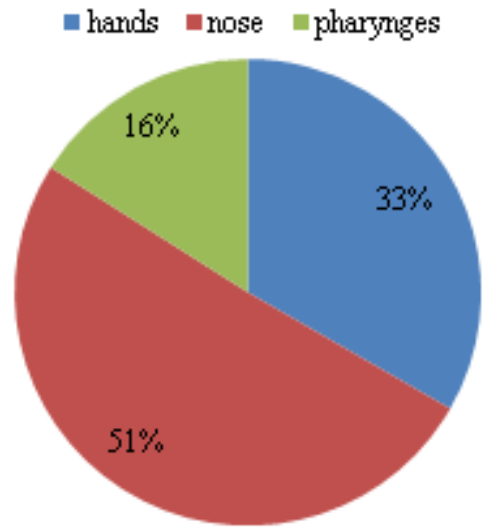

Chart 1: The isolates positivity from the hands, throat and nose

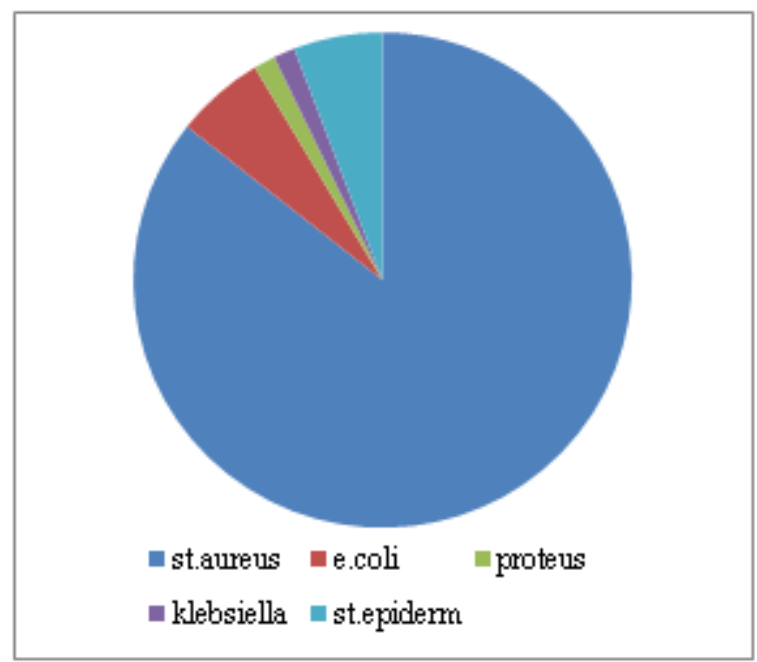

Chart 2: The positivity of the isolates for the respective pathogen

\section{Conclusions}

1) The high percentage of pathogenic isolates through healthcare workers at the Regional Hospital of Korca indicates a high potential risk of nosocomial infections in the hospital.

2) The most common pathogen is Staphylococcus aureus.

3) The higher percentage of the positive isolates is found in the nose of the healthcare workers.

4) Washing with soap and water is much less effective than hygienic hand disinfection.

5) The staff is not well trained in guidelines for prevention of nosocomial infections.

\section{Recommendations}

The recommendations for the healthcare workers are to:

1) To recognize the protocols for prevention of nosocomial infections.

2) Wash their hands.

3) Wear gloves.

4) Use facial protectors for example: masks. 


\section{References}

[1] Spaulding E. Chemical disinfection and antisepsis in the hospital. J Hosp Res 1972;9:5-31.

[2] Garner JS, Favero MS. CDC guidelines for the prevention and control of nosocomial infections. Guideline for handwashing and hospital environmental control, 1985.Supersedes guideline for hospital environmental control published in 1981. Am J Infect Control 1986;14:110-29.

[3] Sehulster L, Chinn R, Arduino M, Carpenter J, Donlan $\mathrm{R}$, Ashford D, et al. Guidelines for environmental infection control in health-care facilities: recommendations of $\mathrm{CDC}$ and the Healthcare Infection Control Practices Advisory Committee (HICPAC). 2003.

[4] Prevention and Control of Nosocomial Infections (4th Edition), RP Wenzel (Ed). Baltimore: Lippincott Williams \& Wilkins, 2003.

[5] Dancer SJ. Importance of the environment in methicillin-resistant Staphylococcus aureus acquisition: the case for hospital cleaning. Lancet Infect Dis 2008;8:101-13.

[6] Hospital-Aquired Infections ( Julia B. Wilcox ) 2009

[7] Centers for Disease Control and Prevention. 2011. Guide to infection prevention for outpatient settings.

[8] Centers for Disease Control and Prevention, NIOSH. 2012. Workplace safety \& health topics: healthcare workers. Available from: http://www.cdc.gov/niosh/ topics/healthcare/.

[9] Guideline for isolation precautions: Preventing transmission of infectious agents in healthcare settings. 2014. Mar 10

[10] WHO guidelines on hand hygiene in health care: A summary. 2014. Mar 10 